\title{
El patrimonio gastronómico de México y sus regiones
}

\author{
Leticia Ivonne del Río Hernández, José Francisco Román Gutiérrez | Universidad Autónoma de Zacatecas
}

URL de la contribución <www.iaph.es/revistaph/index.php/revistaph/article/view/3889>

La declaratoria de la cocina tradicional mexicana como Patrimonio Cultural de la Humanidad, desde el año 2010, permitió vislumbrar un proyecto donde la sustentabilidad es la clave del desarrollo social, cultural y económico de un país que busca ávidamente baluartes de su identidad.

Restaurantes y diversos negocios gastronómicos ofrecen "recetas de la abuela", atesoradas como un bien intangible, y aparecidas en la escena pública con la certeza de que su antigüedad las provee de un halo patrimonial que nos debe interesar a todos.

Nos congratulamos de la declaratoria pero aún no logramos entender el carácter aglutinador y cohesionador de semejante acierto. La producción, distribución y consumo de alimentos deben ser valorados como parte del patrimonio gastronómico, integralmente reconocidos. Sigue siendo una promesa, un sueño, una utopía, la reactivación del sector agropecuario gracias al valor añadido por la declaratoria.

Para quienes gozan de un mayor estatus económico las prácticas de consumo gastronómico permanecen alejadas de fórmulas sencillas y accesibles para todos. Maíz, frijol, chile y nopales (chumberas) son materia prima de sopas, platillos, bebidas y postres que la añoranza ha hecho viajar a la Unión Americana y otros destinos donde los migrantes mexicanos llevan, junto a sus recuerdos, quesos rancheros, añejos y enchilados. El pinole (gofio), fácil de transportar, conservar y paladear, es un producto estrella de las comunidades rurales de México llevado a las grandes urbes del mundo. Caben las preguntas ¿qué es patrimonio cultural? ¿las recetas deben permanecer inalterables por su antigüedad o son más bien producto del paisaje natural, condiciones de vida y posibilidades económicas de las distintas poblaciones? ¿eso les provee de la connotación de patrimonio?
Entender la gastronomía como un conjunto de paisajes culturales nos remite al campo, a los mercados, a las cocinas y, hoy en día, a la comercialización en diversas latitudes donde los clichés gastronómicos simplifican la oferta a totopos, chile y guacamole, haciendo invisible la gran riqueza y variedad gastronómica surgidas de productos locales.

Considerar las variedades de maíz y frijol como patrimonio cultural permite su defensa frente a la producción de trangsénicos no sólo por su especificidad biológica sino porque son la esencia de platillos que, de otra manera, desaparecerían.

Valga como ejemplo el tejuino, bebida hecha a base de maíz "criollo" denominado pipitillo, en peligro de desaparición por el cultivo de maíz genéticamente modificado en los campos zacatecanos. El tejuino es pieza fundamental de la fiesta patronal del pueblo de Nochistlán, Zacatecas, donde se celebra al Güerito (rubio) San Sebastián ofreciendo la bebida como afirmación religiosa, identitaria y gastronómica. En primavera-verano se cosecha el maíz; en otoño se organizan los barrios para la elaboración ingente de miel de maíz. Durante la semana previa al 20 de enero, residentes y visitantes convergen para disfrutar por las noches el tejuino $y$, por las mañanas, el menudo (callos madrileños). Si desaparece el grano, se puede perder una de las fiestas patronales más significativas de la entidad, por su ritualidad, y numero de asistentes.

La importancia está en la mirada de los sujetos, en las prácticas y costumbres que cohesionan al pueblo más allá de sus fronteras. En estas fechas Nochistlán se convierte en una comunidad binacional, donde el inglés y el español conviven con naturalidad. Matrículas de Chicago, California, New York, Texas, son tan comunes como las de Guadalajara, Zacatecas o Durango. 
Esta semilla le da sentido a la convivencia, a la celebración, al intercambio cultural, a la elaboración de castillos de pólvora, conservación de danzas tradicionales, composiciones musicales, recorridos expiatorios a través de las peregrinaciones, producción de pinole, acopio y reparto de naranjas, dulces y cacahuates en un festín simbólico que hunde sus raíces en tiempos prehispánicos y virreinales.

¿Quién debe participar en la discusión sobre qué es el patrimonio cultural? Entender las fiestas patronales sólo como algo estético, deja fuera la emotividad flagrante que derrochan los participantes.

Decidir cómo abordarlo, intervenirlo o utilizarlo, es extraordinariamente complejo porque podría tergiversar las expresiones culturales que han sobrevivido durante siglos sin intervención de autoridades políticas o académicas. Cambiar una manifestación cultural por motivos económicos y sociales podría generar el desmantelamiento de estructuras organizativas de gran arraigo familiar, local y/o regional. Más valdría conformarse con valorarlo, vivirlo, comprenderlo y registrarlo para evitar su desaparición.

Por otro lado, los fenómenos sociales tienen su propia lógica y adaptación. Las comunidades de migrantes exitosos no encuentran mejor inversión que volver a su pueblo durante las fiestas del Güerito San Sebastián para ofrecer, junto a la tradicional bebida, música de mariachi, banda y diversión. La comunidad local, la que se queda, encuentra en esta fiesta el mejor regalo para evocar la tierra, la familia, la tradición.

Varios académicos han puesto en valor esta manifestación, impulsando su registro y divulgación. Con ello han despertado el interés de la autoridad municipal, secretaría de turismo y empresas turísticas. Asimismo, las nuevas tecnologías hacen accesible el disfrute de la fiesta desde distintos ángulos y generaciones, desde los más ortodoxos que buscan la originalidad y autenticidad en la memoria histórica, hasta los que disfrutan el evento en su expresión religiosa.

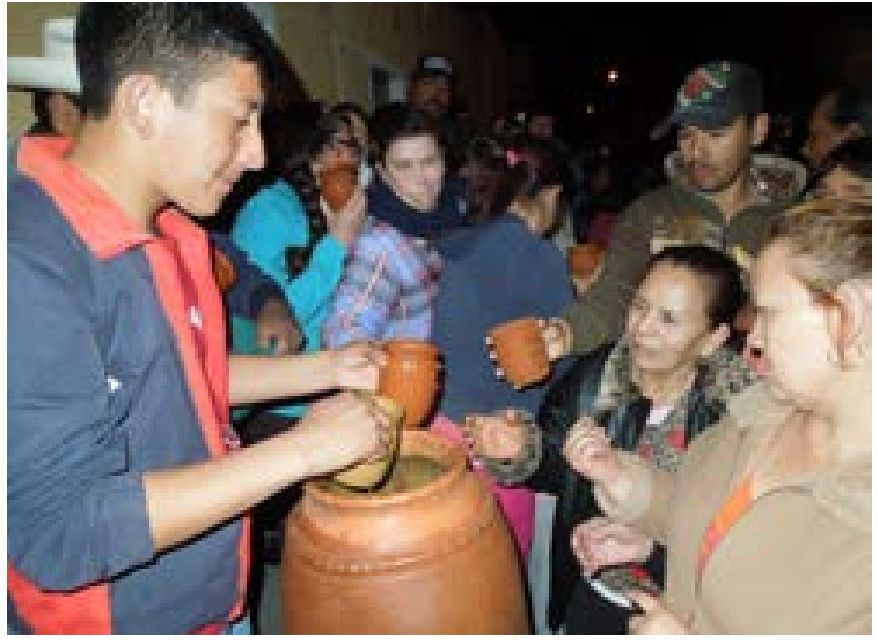

El tejuino, una bebida para todos en honor a San Sebastián | foto Leticia Ivonne del Río Hernández, José Francisco Román Gutiérrez

Este es un fenómeno que no puede permanecer inalterable, por la conjunción de diferentes tradiciones, espacios comunitarios y personas que viven en México y en los Estados Unidos y, sin embargo, buscan su razón de ser en la herencia que han recibido y quieren conservar.

La innovación tiene un límite. Los anclajes culturales y el cambio generacional no pueden ir en sentidos contrarios si quieren conservar su fiesta: la necesidad de defender el maíz pipitillo en escenarios productivos, económicos y políticos responde a la pregunta sobre quién debe participar de las discusiones sobre qué es patrimonio. No sólo los intelectuales y autoridades tienen el privilegio de plantear esa pregunta: los colectivos, en cualquier lugar del planeta, deben responder a las preguntas ¿quiénes somos? ¿qué tenemos? ¿qué queremos transmitir a las siguientes generaciones? 